\title{
A ARTICULAÇÃO RELIGIÃO-POLÍTICA NO DISCURSO POLÍTICO: ANÁLISE DE UM PRONUNCIAMENTO DO CABO DACIOLO SOB A ÓTICA DA TEORIA SEMIOLINGUÍSTICA DE CHARAUDEAU
}

\author{
MÔNICA SANTOS DE SOUZA MELO ${ }^{1}$ \\ SAID SLAIBI ARAUJO2 \\ Departamento de Letras \\ Universidade Federal de Viçosa \\ Av. Ph Rolfs, s/n. - 36570-000 - Viçosa - MG \\ monicamelo@ufv.br, said.araujo@ufv.br
}

\begin{abstract}
Resumo. Nosso artigo aborda a interseção entre os discursos religioso e político, por meio da análise de um pronunciamento parlamentar do exdeputado federal, Cabo Daciolo, realizado em plenário em 2017, período que antecede sua candidatura oficial às eleições presidenciais. Adotou-se a Teoria Semiolinguística de Patrick Charaudeau, além de pressupostos que exploram a relação entre religião e sociedade. O trabalho teve como objetivo analisar as relações interdiscursivas entre esses dois dominios, visando, sobretudo, a identificação dos ethé e a interpretação dos imaginários projetados. Os resultados obtidos apontam para um uso constante do discurso religioso para validar o posicionamento político de Daciolo.
\end{abstract}

Palavras-chave: análise do discurso; religião; política.

\begin{abstract}
Our paper studies the intersection between religious and political discourse. It analyzes a parliamentary pronouncement of former federal deputy, Cabo Daciolo, held in plenary in 2017, period that precedes his official candidacy for presidential elections. This work was done based in the Semiolinguistic Theory of Patrick Charaudeau, besides assumptions exploring the relation between religion and society. The work aimed to analyze the interdiscursive relations between these two domains, aiming, above all, the identification of the ethe and the interpretation of the projected imaginaries. The results obtained point to a constant use of religious discourse to validate the political position of Daciolo.
\end{abstract}

Keywords: discourse analysis; religion; politics.

\footnotetext{
${ }^{1}$ Doutora e Pós-Doutora em Estudos Linguísticos (UFMG). Professora Titular da Universidade Federal de Viçosa. Bolsista de Produtividade em Pesquisa do CNPq. Agradecemos o apoio do CNPq para essa pesquisa.

${ }^{2}$ Graduando em Letras pela Universidade Federal de Viçosa. Bolsista de Iniciação Científica (CNPq).
} 


\section{INTRODUÇÃO}

$\mathrm{O}$ presente artigo $^{3}$ se propõe a analisar um pronunciamento realizado em Congresso em setembro de 2017 pelo deputado federal Cabo Daciolo. Busca-se observar a interseção entre os discursos político e religioso e a mútua influência entre eles, analisando as principais estratégias discursivas empregadas pelo locutor, bem como o ethos gerado e os imaginários sociodiscursivos projetados.

Uma vez que a religião é um fenômeno coletivo, que possui o poder de afetar tanto as relações sociais quanto a vida pública, torna-se necessário estudá-la em razão de sua capacidade de influência. A influência da religião, ou sua "função social" tem sido objeto de discussão de muitos estudiosos, especialmente do campo da Sociologia, dentre os quais, Bourdieu.

Bourdieu (2007) retoma Durkheim e Weber para, a partir deles, se posicionar a respeito do poder simbólico da religião. Concorda com Durkheim (2000), para quem a religião exerce "funções sociais", promovendo representações coletivas. Para Durkheim, a religião exerce, também, funções políticas em favor das diferentes classes sociais de uma determinada formação social, graças a sua eficácia simbólica. Bourdieu também reflete a respeito da contribuição de Weber (1999), para quem o sistema de crenças e de práticas religiosas funcionam como estratégias de diferentes grupos de especialistas que lutam pelo monopólio da gestão dos bens de salvação, em favor das diferentes classes por eles representadas. Para Weber, a religião deve ser estudada à luz de uma sociedade do poder e cumpre uma função de conservação da ordem social, contribuindo para a legitimação do poder dos dominantes e para a domesticação dos dominados.

Avaliando a posição desses dois sociólogos, Bourdieu conclui que a religião, como sistema simbólico:

(...) contribui para a imposição (dissimulada) dos princípios de estruturação da percepção e do pensamento do mundo e, em particular, do mundo social, na medida em que impõe um sistema de práticas e de representações cuja estrutura objetivamente fundada em um princípio de divisão política apresenta-se como a estrutura natural - sobrenatural do cosmos. (BOURDIEU, 2007, p. 33-34)

Nessa perspectiva, a religião é considerada um vetor de poder simbólico, que tende a favorecer a divisão social, promovendo uma conservação da ordem social.

Nosso estudo se justifica, portanto, devido à crescente influência da religião na sociedade, em função de uma maior visibilidade de figuras da esfera religiosa atuando no cenário político, que produzem discursos influenciados pela religião.

As manifestações advindas dessa problemática tornaram-se mais evidentes quando, em 2014, à época do processo de impeachment da ex-presidente Dilma Rousseff, parlamentares buscaram fundamentar, na religião, suas tomadas de posição frente à decisão final.

\footnotetext{
${ }^{3}$ Os dados expostos aqui são frutos de uma pesquisa de Iniciação Científica financiada pelo CNPq, que, por sua vez, se insere num projeto de pesquisa mais amplo.
} 
Tendo em mente essas manifestações e sua potencial força persuasiva, haja vista que a população brasileira encontra-se submetida a esses discursos, considera-se, então, a influência exercida na sociedade pela religião. Para Burity (2008, p. 84):

Não se pode mais ignorar a visibilidade pública da religião na cena contemporânea. Quer no plano da cultura e do cotidiano, quer no da esfera pública e da política, os atores religiosos movimentam-se e trazem a público sua linguagem, seu ethos, suas demandas, nas mais diversas direções. (BURITY, 2008, p. 84).

A reflexão a respeito da presença da religião no espaço público nos conduz à questão das relações de poder no âmbito religioso. A esse respeito Lemos (2005, p. 28) destaca que:

A religião é um sistema de símbolos que atua para estabelecer poderosas, penetrantes e duradouras disposições e motivações nos seres humanos. Ela pode tanto fornecer a explicação e a justificação das relações sociais como construir o sistema de práticas destinadas a reproduzi-las. (LEMOS, 2005, p. 28).

Consideramos, portanto, que a religião é uma instância de poder. Para Van Dijk (2008), as relações de poder social pressupõem uma estrutura ideológica e se manifestam na interação, através das ações reais ou potenciais de um grupo pelas quais ele exerce um controle social sobre outro. A manutenção desse poder se faz de forma indireta, através de persuasão que se efetiva por meio do discurso. Esse poder relaciona-se, ainda, ao campo e à extensão dos agentes de poder. Em geral, o poder desses agentes, assim como a extensão de suas ações, se restringem a um domínio social (política, religião, direito), mas podem ultrapassá-lo. É o que acontece com agentes oriundos do campo religioso, que atuam e exercem influência também no domínio político, ou com agentes políticos que recorrem à religião para fundamentar suas propostas.

Portanto, pensando em manifestações como, por exemplo, a da chamada 'Bancada da Bíblia', constituída de parlamentares cristãos legitimados para defender os interesses gerais da nação, e que o fazem sob um viés religioso, discursando "a favor da moralização da coisa pública" (FIGUEIREDO FILHO, 2002), elegemos como objeto de estudo a figura cristã-política de Cabo Daciolo, reconhecido, principalmente, por seus inflamados discursos, quase sempre marcados por referências ao campo religioso.

No presente artigo, apresentaremos, a princípio, os pressupostos teóricos e metodológicos adotados; em seguida, serão descritos o gênero e o contrato de comunicação do discurso analisado. Identificaremos as principais estratégias discursivas utilizadas para, finalmente, abordar a construção do ethos e a proposição de imaginários no pronunciamento em questão. 


\section{PRESSUPOSTOS TEÓRICO-METODOLÓGICOS}

Adotamos como eixo teórico-metodológico a Teoria Semiolinguística do Discurso, de Charaudeau, e trabalhos do mesmo autor, que visam à compreensão das categorias do ethos e dos imaginários sociodiscursivos.

Trata-se de um estudo de natureza qualitativa, que visa identificar aproximações entre os discursos político e religioso e os imaginários sociodiscursivos projetados a partir dessas aproximações. Para isso, será necessário descrever o contrato subjacente à situação analisada, incluindo as identidades dos parceiros, finalidades e circunstâncias materiais envolvidas.

Quanto aos procedimentos de ação, foi feita a transcrição do pronunciamento, que precedeu a descrição e análise dos dados. $\mathrm{Na}$ etapa subsequente, o pronunciamento foi descrito a partir das categorias dos modos enunciativo, descritivo e argumentativo, conforme Charaudeau (2016). Por fim, foram analisados o ethos e os imaginários projetados, tomando por base os trabalhos de Charaudeau (2017a e 2017b), respectivamente. Na sequência, apresentaremos a descrição da configuração do gênero pronunciamento parlamentar para, em seguida, descrever e analisar a fala do deputado Daciolo, conforme as diretrizes apresentadas acima.

\section{GÊNERO E CONTRATO DE COMUNICAÇÃO}

De acordo com Charaudeau (2004), o gênero de um texto deve ser descrito a partir de quatro dimensões: a ancoragem social, a natureza comunicacional, as atividades linguageiras e as características formais do texto.

Charaudeau entende que a configuração dos gêneros passa pela obediência a três tipos de restrições. Em primeiro lugar, as restrições situacionais, responsáveis por fornecer uma gama de dados situacionais; estes, por sua vez, influenciam as restrições discursivas - os modos de organização discursivos (enunciativo, descritivo, narrativo e argumentativo). Por fim, os gêneros obedecem a restrições formais, que se relacionam com os tipos de orações, as escolhas lexicais feitas, as estruturas frasais e à linguagem utilizada.

Segundo o autor, a situação de comunicação fornece uma série de elementos responsáveis por dar suporte às condições de produção do discurso, a saber: $i$ ) a identidade do (s) parceiro (s) linguageiro (s), ii) o propósito, iii) as condições materiais de produção $\mathrm{e}$, por último, $i v)$ a finalidade.

Em relação à identidade do locutor, Cabo Daciolo é homem, heterossexual, cristão, político e bombeiro militar. O lugar social de deputado federal lhe dá legitimidade para falar em Congresso e ter autoridade frente aos seus interlocutores - a sociedade - e uma identificação frente aos demais parlamentares. Além disso, Daciolo é pastor, ocupando um lugar social que lhe dá legitimidade para tratar de assuntos ligados à esfera religiosa. Conciliando essas identidades, Daciolo pode ser reconhecido como um dos primeiros políticos a promover uma espécie de transformação do palanque em púlpito. Sendo assim, seus discursos parecem se converter em verdadeiras pregações. Embora 
tenha, teoricamente, a legitimidade para falar em nome de Deus, já que é vinculado a igrejas evangélicas de linha neopentecostal, não demonstra, em seus discursos, um conhecimento teológico aprofundado. Em suas falas, predominam alguns lugares-comuns que denunciam um conhecimento superficial da doutrina cristã. No próprio discurso em análise, sua fala contradiz o texto bíblico quando afirma que o homossexual é comparável a adúlteros, alcoólatras e ladrões e que nenhum desses vai "herdar o reino de Deus."

Enquanto deputado, sua atuação foi centrada na defesa dos interesses dos militares e na tentativa de transformar o Brasil em uma teocracia. Como parlamentar, tentou modificar o parágrafo primeiro da Constituição (Todo poder emana do povo) para "Todo poder emana de Deus", contrariando os princípios do Estado laico. Passou, no mundo político, a ser considerado como uma figura meio caricata, em função de algumas atitudes, tais como, a profecia de que o ex-deputado federal Jean-Wyllys iria se casar com uma mulher e ter filhos e que a deputada tetraplégica Mara Gabrilli voltaria a andar. ${ }^{4}$ Nenhuma dessas profecias se cumpriu. No período da campanha às eleições presidenciais também chamou a atenção pelo fato de ter ido para um monte, em oração, e ter se mantido lá em jejum e oração por 21 dias. Suas falas se caracterizam pela presença da exortação "Glória a Deus!", que se tornou uma marca de seus discursos.

Quanto ao propósito, pode-se elencar quatro temáticas na enunciação analisada: uma denúncia e crítica à corrupção no Brasil; uma defesa da ideologia cristã, de vertente evangélica; uma defesa do militarismo e dos militares e uma autopromoção de sua figura política, a qual é apresentada como uma alternativa aos políticos usuais para a população brasileira.

Com relação às condições materiais de produção, há no discurso uma dupla enunciação, que deriva do fato de que a fala é realizada de forma presencial e utiliza como canal a voz do sujeito enunciador e os outros parlamentares como interlocutores, mas, também, é uma enunciação mediada pelos meios de comunicação, como a televisão e a internet tendo como principais canais de veiculação a TV Senado e o site da Câmara dos Deputados.

Quanto à finalidade do discurso, pode-se inferir que o pronunciamento parlamentar visa abordar um tema de interesse público, defendendo teses que visem o bem comum. Contudo, tal situação é também uma oportunidade para a autopromoção do político diante dos colegas parlamentares e de toda a população que tem acesso ao discurso. O pronunciamento em questão é, portanto, uma tentativa de persuadir os interlocutores e fazê-los acreditar que a figura política de Cabo Daciolo é singular, diferenciada em relação aos demais políticos e digna de confiança. Portanto, também pode-se enquadrar a finalidade de sua fala como autopromoção, o que nos permite supor que essa enunciação já é um prenúncio de uma candidatura que está por vir.

No que concerne à restrição discursiva, os modos de organização argumentativo e descritivo são os mais presentes, uma vez que a finalidade da enunciação se pauta na tentativa de persuasão dos interlocutores e na autopromoção.

${ }^{4}$ Disponível em https://ultimosegundo.ig.com.br/politica/2018-08-10/cabo-daciolo-debate.html. Acesso em 19 ago. 2020. 
Em relação às restrições formais, as escolhas lexicais evidenciam, além de expressões típicas do campo político, outras oriundas tanto da esfera do militarismo quanto da religiosidade. Destaca-se que pode ser observada a utilização de termos como "militarismo", "patriotismo", "civismo", "defesa da Pátria", que, no cotidiano caíram em desuso e que remetem a um campo semântico do Brasil das décadas de 1960 e 1970.

Ao adotar as categorias de Charaudeau (2004), pode-se chegar à conclusão de que o discurso de Cabo Daciolo pertence ao gênero pronunciamento parlamentar. Esse gênero pode ser caracterizado pela figura de um personagem político que fala pelo cidadão e que realiza sua enunciação se dirigindo tanto aos demais parlamentares quanto à população de forma geral.

Entretanto, no discurso em questão, o sujeito enunciador mescla esse gênero com um discurso de autopromoção de sua imagem como um político diferenciado. Nota-se uma constante tentativa por parte do locutor de ressaltar sua identidade de pastor que, embora sendo um deputado democraticamente eleito, se distingue dos demais por uma espécie de "imunidade" ou "santidade", a ponto de se sentir à vontade para se referir aos colegas congressistas como "quadrilha", para conclamar a população a fechar o Congresso Nacional e para defender a instauração de Intervenção Federal e Governo Provisório. Agindo dessa forma, mostra-se como uma alternativa aos políticos tradicionais, que pode atender a demandas de um eleitorado de tendência extremista, nas eleições presidenciais que se aproximavam. Logo, Daciolo extrapola o gênero pronunciamento parlamentar uma vez que, junto a este, encontram-se características do discurso de campanha.

Verifica-se, portanto, que no discurso há como temática a proposta de uma mudança no cenário político, no qual Cabo Daciolo se insere como a melhor alternativa.

\section{IDENTIDADE SOCIAL, DISCURSIVA E ESTRATÉGIAS DISCURSIVAS}

Existem dois traços identitários estabelecidos na competência comunicacional, segundo Charaudeau (2009): a identidade social e a identidade discursiva. O primeiro traço é relacionado à legitimidade de fala do sujeito e deve ser reconhecida socialmente para que seja efetiva. De acordo com o linguista: “(...) designa o estado ou a qualidade de quem é autorizado a agir da maneira pela qual age" (CHARAUDEAU, 2009, p. 314). Em contrapartida, o segundo traço refere-se à forma pela qual a enunciação se desenvolve e abrange duas estratégias: as de credibilidade, ligadas ao crédito que as asserções recebem do destinatário e subdivididas em três atitudes discursivas - neutralidade, distanciamento e engajamento -, e as de captação, as quais, por sua vez, são ligadas à necessidade de persuasão do interlocutor. Três atitudes discursivas são destacadas: polêmica, sedução e dramatização.

Inserido em uma situação política, é demandado ao sujeito político que construa sua enunciação de modo a defender suas teses e garantir seus valores e que, concomitantemente, exerça influência sobre seu interlocutor com a finalidade de que este adote os ideais do político. A partir de Charaudeau (2009): 
Compreende-se então como o resultado desta combinação produz um "Eu-nós", uma identidade do singular-coletivo. O homem político, em sua singularidade, fala por todos: enquanto portador de valores transcendentes, sua voz é a voz de todos... Mas, ao mesmo tempo, dirige-se a estes "todos" como se fosse apenas o porta-voz de um terceiro, o enunciador de uma idealidade social. A partir de então, estabelece um "pacto de aliança" entre estes três tipos de vozes (a voz do Terceiro, a voz do EU, a voz do TU-todos) que acabam por fundirse num corpo social abstrato, muitas vezes expresso por uma construção indefinida ou por um "nós. (CHARAUDEAU, 2009, p. 320).

Como vimos, Daciolo concilia as identidades sociais de deputado e de pastor, o que lhe confere, pelo menos teoricamente, condições para tratar de questões das esferas política e religiosa. Porém, observa-se que, em alguns momentos, sua identidade de pastor parece se sobrepor à de político, havendo a referência a trechos bíblicos que fazem com que seu discurso em vários momentos se assemelhe mais a uma pregação do que a um pronunciamento parlamentar. Essa interseção entre os domínios religioso e político pode ser vista como uma estratégia, que serve para diferenciar o deputado dos demais políticos, favorecendo a captação de parte do público, especialmente o segmento cristão. Exemplos:

(1) O que eu falo hoje é para a Nação brasileira. Deus criou o homem e a mulher. Em determinado momento, abençoou e disse: 'Sejam férteis e multipliquem-se. Encham e subjuguem a Terra'.

(2) Eu peço àqueles homens e mulheres - e agora eu falo com os cristãos - observem como vai votar a bancada evangélica. Fiquem de olho como vai votar aqueles que falam de Deus. Eu quero deixar uma coisa: Deus criou homem e mulher - homem e mulher! Então, alguns olham para o cisco nos olhos de alguns, mas não conseguem ver a trave nos seus olhos. O homossexualismo é pecado, e está escrito: não vai para o céu. Assim como o alcoólatra, assim como o adúltero, assim como o ladrão, o corrupto. Esses também não vão herdar o reino de Deus.

(3) Glória a Deus! Obrigado, Senhor! Obrigado, Presidente.

Em relação à estratégia de "credibilidade", parte da identidade discursiva, a atitude de engajamento é a mais expressiva no discurso, uma vez que Cabo Daciolo se implica em sua argumentação e assume uma posição frente aos tópicos que são propostos. Nas palavras de Charaudeau (2009): "Esta atitude destina-se a construir a imagem de um sujeito falante como "ser de convicção". A verdade, aqui, confunde-se com a força de convicção daquele que fala, e espera-se que esta influencie o interlocutor." (CHARAUDEAU, 2009, p. 316).

Referente à estratégia de "captação", observam-se as atitudes discursivas de polêmica, pela qual há uma tentativa de descrédito de seus adversários e de partidos políticos, ao passo que ele constrói uma imagem de exaltação do militarismo, como em:

(4) Eu estou falando com homens e mulheres da Nação brasileira que apoiam o patriotismo, que apoiam o nacionalismo, que apoiam o civismo, que apoiam a defesa da Pátria, as instituições, (o, a, a...) a garantia da ordem e da lei, que apoiam os militares da Nação, as Forças Armadas, que apoiam e são contra o sucateamento das Forças Armadas, 
aos baixos salários dos militares, e que são contra a essa quadrilha que está instaurada no Congresso Nacional, que são contra a essa falsa reforma política que está acontecendo hoje aqui no Congresso Nacional, que são contra a organização criminosa que envolve PT, que envolve $\mathrm{PMDB}$, envolve PP, envolve PSDB e envolve grande parte dos partidos da Nação brasileira.

Observa-se, também, a estratégia de sedução, através da qual ele se dirige à população e se coloca, por intermédio do uso do nós, como alguém presente e integrante do povo, ao mesmo tempo que contrastivo em relação aos demais políticos:

(5) Nação brasileira, juntos somos fortes! Nenhum passo daremos atrás! E Deus está no controle! Coloquem a bandeira do País na nossa casa e no nosso lar, em defesa da Nação brasileira. Juntos somos fortes! Nenhum passo daremos atrás! E Deus está no controle!

Constata-se ainda a presença da estratégia de dramatização, através de uma contraposição entre o mundo dos homens e de Deus, e de um valor afetivo por detrás dela:

(6) E agora, eu quero dar um recado a uma grande vilã da Nação brasileira. Eu estou falando da Rede Globo. Rede Globo, você é grande para os homens, para Deus, você é pequenininha, Rede Globo.

A autoridade do locutor advém da associação entre a legitimidade e a credibilidade, ou seja, é menos provável que alguém com legitimidade, mas sem credibilidade, ou vice-versa, consiga atingir seus objetivos em uma situação política do que alguém que reúna esses dois atributos.

\section{OS MODOS DE ORGANIZAÇÃO}

Os modos de organização do discurso são procedimentos linguísticos que são ordenados em categorias em função das finalidades do ato de comunicação. Compreendemos a existência de quatro modos de organização a partir de Charaudeau (2016): o modo de organização enunciativo, o modo de organização descritivo, o modo de organização narrativo 5 e modo de organização argumentativo. Devido à extensão das categorias em cada um dos modos, aqui será feito um recorte para se trabalhar somente com as categorias mais relevantes para a análise.

\section{A ORGANIZAÇÃO DISCURSIVA DO PRONUNCIAMENTO DO CABO DACIOLO: PRINCIPAIS PROCEDIMENTOS}

Na perspectiva semiolinguística, todo discurso revela a posição assumida pelo enunciador em relação ao dito e ao outro, por meio de modalidades do chamado modo de organização enunciativo. Nesse modo, são previstos três tipos de enunciação: a enunciação elocutiva, realizada através de pronomes pessoais de primeira pessoa e do uso de verbos flexionados também em primeira pessoa; a enunciação alocutiva, realizada

\footnotetext{
${ }^{5}$ Não será trabalhado neste artigo.
} 
através de pronomes pessoais de segunda pessoa, de verbos flexionados nessa pessoa e de denominações de tratamento, de forma a implicar o interlocutor no discurso e a enunciação delocutiva, realizada através de um "apagamento" da voz do locutor, como se o dito fosse enunciado por uma terceira voz, a qual enuncia "...uma verdade que não depende nem do $e u$, nem do $t u$, pois ela tem valor em si” (CHARAUDEAU, 2017a, p. 179). Para a Semiolinguística, o reconhecimento do posicionamento predominante é um requisito inicial para a abordagem de qualquer discurso.

Sendo assim, no discurso de Cabo Daciolo, as enunciações elocutiva e alocutiva são as mais recorrentes, pois ocorre uma constante interpelação dos interlocutores e um uso frequente dos pronomes eu e nós. A predominância dessas modalidades revela um discurso "inflamado", em que o locutor interpela o seu ouvinte, incitando-o a executar determinadas ações. No discurso em questão, temos uma tentativa de mobilizar o interlocutor a ações que culminariam no fechamento do Congresso Nacional e na instauração de um Governo provisório, dentre outras medidas anticonstitucionais. $\mathrm{O}$ uso da primeira pessoa denuncia uma fala em que predominam saberes de crença (como veremos ao abordar os imaginários sociodiscursivos), no qual o locutor se pauta muito mais em crenças do que em conhecimentos, e por meio do qual este locutor tenta criar uma identificação com os interlocutores, sejam eles os demais parlamentares, sejam os internautas que assistirão seu pronunciamento e que seriam eleitores em potencial nas próximas eleições, o que indica um discurso de autopromoção de um eventual candidato no pleito eleitoral que se aproximava.

Vejamos, em seguida, as principais estratégias identificadas no discurso, referentes às organizações descritiva e argumentativa do discurso.

\section{A ORGANIZAÇÃO DESCRITIVA}

A organização descritiva diz respeito ao modo pelo qual o sujeito insere objetos no mundo textual através de procedimentos como nomear, localizar-situar e qualificar.

Em relação ao primeiro aspecto, nota-se, no discurso analisado, a denominação de figuras religiosas, de uma rede de televisão e de um apresentador vinculado a ela, de figuras ligadas ao militarismo, de partidos políticos e das forças armadas. Em relação ao segundo aspecto, define-se o espaço como o país, Brasil, mais especificamente, o Congresso Nacional. No tocante ao terceiro aspecto, há a qualificação positiva de Cabo Daciolo por ele mesmo de forma implícita como alguém temente a Deus e patriota:

(7) Eu quero dizer para você, Nação brasileira que está me ouvindo neste exato momento, àqueles que acreditam na Nação brasileira, na Bandeira Nacional, que nós venhamos colocar em nossas casas, nas janelas, (no, na, na...) na varanda, em todos os lugares da tua residência, a Bandeira Nacional...

Também, há a qualificação positiva de figuras ligadas ao militarismo:

(8) O General Villas Bôas, o General Bacelar, (o, o...) o Brigadeiro Rossato, o, o, o General, o Almirante... - ah!, glória a Deus! -, todos eles têm que ser condecorados, condecorados! 
Por outro lado, observa-se a qualificação negativa de partidos políticos brasileiros e de parlamentares do Congresso Nacional:

(9) ...e que são contra a essa quadrilha que está instaurada no Congresso Nacional, que são contra a essa falsa reforma política que está acontecendo hoje aqui no Congresso Nacional, que são contra a organização criminosa que envolve $\mathrm{PT}$, que envolve PMDB, envolve PP, envolve PSDB e envolve grande parte dos partidos da Nação brasileira.

A qualificação também negativa da Rede Globo e de um apresentador desta emissora, Pedro Bial:

(10) $\mathrm{O}$ que eu quero deixar muito claro aqui: se tem alguém para ser punido, quem tem que ser punida é a Rede Globo, é aquela que vem destruindo a família tradicional do País, é aquela que vem destruindo a Nação brasileira e tirando do povo o amor à Pátria, é aquela que vem dando contrainformação o tempo todo para a Nação brasileira, é aquela que é a grande mentora e que está por trás da quadrilha e dessas organizações criminosas do País, a Dona Rede Globo.

(11) Sr. Bial, vocês têm que ser punidos.

E a qualificação negativa de homossexuais, alcoólatras, adúlteros, ladrões e corruptos, que ele atribui, de forma arbitrária, a preceitos religiosos:

(12) Então, alguns olham para o cisco nos olhos de alguns, mas não conseguem ver a trave nos seus olhos. O homossexualismo é pecado, e está escrito: não vai para o céu. Assim como o alcoólatra, assim como o adúltero, assim como o ladrão, o corrupto. Esses também não vão herdar o reino de Deus.

O trecho analisado se enquadra como uma construção subjetiva do mundo, uma vez que expressa "os sentimentos, os afetos e as opiniões do sujeito descritor" (CHARAUDEAU, 2016, p. 125), sendo um texto de declaração, com a finalidade de incitar. Embora, segundo o autor, tal condenação esteja prevista na Bíblia ("está escrito"), essa interpretação não tem respaldo concreto, o que significa uma interpretação deturbada no livro sagrado dos cristãos.

Em relação à encenação descritiva, pode-se dizer que, em alguns momentos, a fala de Daciolo procura criar um efeito de confidencia, promovido através de uma interpelação do leitor/ouvinte:

(13) Eu quero dizer para você, Nação brasileira que está me ouvindo neste exato momento...

(14) Eu peço àqueles homens e mulheres - e agora eu falo com os cristãos - observem como vai votar a bancada evangélica. 
Uma característica desse discurso é o uso de termos do campo semântico que remetem às décadas de 1960 e 1970, que coincidem com o período de ditadura militar no Brasil, como observado em:

(15) Eu estou falando com homens e mulheres da Nação brasileira que apoiam o patriotismo, que apoiam o nacionalismo, que apoiam o civismo, que apoiam a defesa da Pátria, as instituições, (o, a, a...) a garantia da ordem e da lei, que apoiam os militares da Nação, as Forças Armadas, que apoiam e são contra o sucateamento das Forças Armadas...

O uso de expressões como Nação, civismo, Pátria, patriotismo, garantia da lei e da ordem parece resgatar, de forma saudosista, o período em que o país esteve submetido ao regime militar, corroborando uma imagem positiva desse regime e das Forças Armadas.

\section{A ORGANIZAÇÃO ARGUMENTATIVA}

A organização argumentativa do presente discurso se refere a uma situação comunicativa de finalidade persuasiva, na qual aquele que fala busca fazer com que o seu público destinatário tenha aderência pelos ideais propagados pela enunciação. A análise dessa aderência ou adesão aos discursos se insere no âmbito dos estudos da recepção, que tem sido alvo de investigações cada vez mais aprimoradas no campo da Análise do Discurso. Esse tipo de abordagem é de grande interesse para as pesquisas nessa área e envolve o reconhecimento e interpretação das diversas reações possíveis da instância de recepção do discurso. Contudo, diante da impossibilidade de discutir, nesse espaço, essa questão, em toda sua complexidade, vamos nos restringir, aqui, a abordar a organização argumentativa do ponto de vista da instância de produção do discurso.

Adotando essa perspectiva, destacamos, a princípio, que a tese principal do discurso de Cabo Daciolo é o pedido do fechamento do Congresso Nacional e a instauração de um Governo Provisório.

No tocante à encenação argumentativa, tem-se três componentes: a proposta, a proposição e a persuasão. No pronunciamento, pode-se definir como proposta a posição de defesa do militarismo e da instauração de um Governo Provisório; como proposição, a falência do patriotismo e a situação negativa dos militares no país e como persuasão o clamor para a população colocar a bandeira do país nas casas, no intuito de demonstrar a indignação em relação à corrupção no país e buscar a instauração de um novo regime; o instigar aos cristãos para prestarem atenção em quem votam e a chamada contra a emissora de televisão, pois, segundo o sujeito argumentante, ela é responsável pelo declínio do patriotismo e da moral cristã no Brasil.

A situação de troca linguageira é monologal, já que não há réplicas ao longo do discurso, e o contrato de comunicação é estabelecido de maneira explícita.

O sujeito argumentante assume uma posição de engajamento em relação a sua própria argumentação, através de argumentação polêmica. Observa-se um processo de acusação: 
(16) ...se tem alguém para ser punido, quem tem que ser punida é a Rede Globo, é aquela que vem destruindo a família tradicional do País, é aquela que vem destruindo a Nação brasileira e tirando do povo o amor à Pátria, é aquela que vem dando contrainformação o tempo todo para a Nação brasileira, é aquela que é a grande mentora e que está por trás da quadrilha e dessas organizações criminosas do País, a Dona Rede Globo.

Apesar da presença de outros domínios, o discurso analisado se constrói majoritariamente no Domínio do Ético, por basear sua argumentação em uma moralidade e por definir os elementos "em termos de bem e de mal" (CHARAUDEAU, 2016, p. 232).

Dentre os procedimentos discursivos, tem-se a comparação por semelhança:

(17) O homossexualismo é pecado, e está escrito: não vai para o céu. Assim como o alcoólatra, assim como o adúltero, assim como o ladrão, o corrupto. Esses também não vão herdar o reino de Deus.

E o questionamento, através da incitação a fazer:

(18) ...observem como vai votar a bancada evangélica. Fiquem de olho como vai votar aqueles que falam de Deus.

Tratando-se dos procedimentos de composição, observa-se a linearidade, em suas etapas - começo, transição e fim- e, também, o vai e vem, uma vez que o sujeito argumentante frequentemente faz uma retomada de elementos no seu discurso, como a tentativa de incitar a população ao patriotismo e a atitude de colocar a bandeira nacional nas casas.

Finalmente, identificamos que um elemento importante para a análise do discurso de Daciolo, além das estratégias identificadas acima, é a imagem que ele constrói de si no discurso, ou seja, seu ethos, que é um fator que pode favorecer a captação do público. Sendo assim, descreveremos os ethé projetados pelo deputado, para, por fim, relacionálos aos imaginários projetados por Daciolo no pronunciamento em foco.

\section{ETHÉ}

Segundo Amossy (2005, p. 9): “Todo ato de tomar a palavra implica a construção de uma imagem para si” (AMOSSY, 2005, p. 9). Essa construção imagética discursiva é o ethos.

Charaudeau (2017a, p. 115) considera que:

De fato, o ethos, enquanto imagem que se liga àquele que fala, não é uma propriedade exclusiva dele; ele é antes de tudo a imagem de que se transveste o interlocutor a partir daquilo que diz. O ethos relacionase ao cruzamento de olhares: olhar do outro sobre aquele que fala, olhar daquele que fala sobre a maneira como ele pensa que o outro o vê. (CHARAUDEAU, 2017a, p. 115). 
A partir desse autor, pode-se compreender o ethos como a expressão de uma imagem construída pelo locutor em seu discurso e demonstrada ao público, uma vez que sua construção se pauta em uma relação triangular entre aquele que fala, aquele para o qual é dirigido o discurso e um ausente, sendo este um ideal ou valor de referência almejado por aquele que fala (CHARAUDEAU, 2017a, p. 137). Portanto, o ethos resulta da relação entre aquilo que é manifestado na enunciação e o conhecimento do interlocutor a respeito de seu locutor de antemão, pois "O sentido veiculado por nossas palavras depende ao mesmo tempo daquilo que somos e daquilo que dizemos." (CHARAUDEAU, 2017a, p. 115).

Tratando especificamente da instância política, afirma Charaudeau (2007, p. 247):

(...) o sujeito político terá recurso a estratégias de construção de imagens de si mesmo, de maneira a se tornar credível aos olhos da instância cidadã (ethos de credibilidade) e atrativo (ethos de identificação) (CHARAUDEAU, 2007, p. 247).

Charaudeau (2017a) identifica diversos ethé pertencentes a essas duas macrocategorias (credibilidade e captação). Na macro-categoria de credibilidade, tem-se os ethé de virtude, sério e competência, enquanto na macro-categoria de identificação tem-se os ethé de caráter, humanidade, solidariedade, chefe, potência e inteligência. O quadro abaixo sintetiza esses ethé:

Tabela 1. Ethé identificados e breves definições

\begin{tabular}{|c|c|}
\hline Ethé Credibilidade & Ligado ao crédito que o enunciador deseja obter de seu público \\
\hline Ethos de Virtude & Expressão de sinceridade e pessoalidade, político deve ser um exemplo \\
\hline Ethos de Competência & Expressão de um saber-agir nas situações \\
\hline Ethé de Identificação & Ligado ao desejo do enunciador de que seu público tenha aderência por suas características \\
\hline Ethos de Solidariedade & Expressão de uma imagem que partilha dos problemas enfrentados pelo povo \\
\hline Ethos de Chefe & Expressão de uma imagem que manifesta um tipo de relação com cidadão \\
\hline Ethos de Potência & Expressão de uma força mais voltada para o fisico e verbal, ligada à virilidade sexual \\
\hline Ethos de Caráter & Expressão de uma força mais interna, voltada para o espírito e para a mentalidade \\
\hline
\end{tabular}

Fonte: Charaudeau (2017a)

No discurso de Cabo Daciolo, verificou-se a manifestação de alguns desses ethé, como os de virtude, solidariedade, chefe, potência e caráter, correspondentes aos exemplos 19 a 23, respectivamente:

(19) Nação brasileira, vamos colocar a bandeira do Brasil em nossos lares, na nossa casa, contra a corrupção no Brasil e pela denúncia, que é a denúncia que foi aprovada no Supremo, que vai vir para cá.

(20) Nação brasileira, juntos somos fortes! Nenhum passo daremos atrás! E Deus está no controle! 
(21) O que eu falo hoje é para a Nação brasileira. Deus criou o homem e a mulher. Em determinado momento, abençoou e disse: 'Sejam férteis e multipliquem-se. Encham e subjuguem a Terra'.

(22) Sr. Bial, vocês têm que ser punidos. O General Villas Bôas, o General Bacelar, (o, o...) o Brigadeiro Rossato, o, o, o General, o Almirante... - ah!, glória a Deus! -, todos eles têm que ser condecorados, condecorados!

(23) O que eu quero deixar muito claro aqui: se tem alguém para ser punido, quem tem que ser punida é a Rede Globo, é aquela que vem destruindo a família tradicional do País, é aquela que vem destruindo a Nação brasileira e tirando do povo o amor à Pátria, é aquela que vem dando contrainformação o tempo todo para a Nação brasileira, é aquela que é a grande mentora e que está por trás da quadrilha e dessas organizações criminosas do País, a Dona Rede Globo.

Em síntese, destacam-se, entre os ethé de credibilidade, a imagem que o deputado tenta passar de virtude, como alguém engajado em boas causas, como o combate à corrupção, e de solidariedade, expresso em enunciações elocutivas, em que se coloca ao lado do povo ("juntos somos fortes"), na consolidação de um projeto de apoio ao "patriotismo". Entre os ethé de identificação, o discurso de Daciolo colabora para a construção de uma imagem adequada a um líder político, o que prenuncia uma provável candidatura nas eleições que se aproximavam. O ethos de caráter reforça a imagem de um político diferenciado, que não se deixa corromper tendo, inclusive, um distanciamento que permite denunciar a existência de uma "quadrilha" entre os congressistas. Os ethé de chefe e de potência se relacionam para a construção da imagem de um político suficientemente forte para conduzir a população rumo àquilo que o deputado considera ser o bem comum.

A proposição desses ethé visa criar uma imagem positiva do deputado, diferenciando-o dos demais políticos e criando uma identificação com um público que compartilha dos mesmos valores defendidos.

\section{IMAGINÁRIOS SOCIODISCURSIVOS}

Segundo Charaudeau (2017b, p. 578):

O imaginário é uma forma de apreensão do mundo que nasce na mecânica das representações sociais, a qual, conforme dito, constrói a significação sobre os objetos do mundo, os fenômenos que se produzem, os seres humanos e seus comportamentos, transformando a realidade em real significante. Ele resulta de um processo de simbolização do mundo de ordem afetivo-racional através da intersubjetividade das relações humanas, e se deposita na memória coletiva. (CHARAUDEAU, 2017b, p. 578).

Portanto, pode-se caracterizar o imaginário como uma forma de reconstrução humana significativa da realidade, a qual é materializada discursivamente. No discurso de Daciolo, observa-se a projeção de alguns imaginários, a saber: 
1. Partidos e políticos são corruptos e destroem a nação;

2. Intervenção Federal e Governo Provisório são a solução para o país;

3. Militares são heróis;

4. Rede Globo é inimiga da família e da política;

5. Homossexualismo 6 é pecado;

6. Deus está no controle.

Verifica-se que há uma tentativa de criminalização da classe política, uma vez que Cabo Daciolo acusa os partidos e seus membros de estarem envolvidos em uma "organização criminosa", além de serem os que estão "matando o povo". Essa imagem não deixa de ser surpreendente, uma vez que o próprio comunicante é também um político. Contudo, como vimos, por meio de uma série de estratégias, Daciolo procura criar para si uma imagem de político diferenciado. Projeta-se como uma espécie de Messias, capaz de anunciar novos tempos. Seu discurso também se caracteriza pela exaltação do militarismo e de militares, tanto que a intervenção federal é colocada como solução para os problemas do país. Também constata-se a inserção do domínio religioso através da forte presença da figura de Deus, constantemente demarcada no discurso.

Para Charaudeau (2017b, p. 582), os imaginários sociodiscursivos se dividem em dois grupos: os saberes de conhecimento e saberes de crença. Evidencia-se na fala de Cabo Daciolo os saberes de crença, pois:

Os saberes de crença não se relacionam com o conhecimento do mundo no sentido que temos que atribuir a ele, mas com as avaliações, apreciações, julgamentos a respeito dos fenômenos, dos eventos e dos seres do mundo, seu pensamento e seu comportamento. O conhecimento, como acabamos de ver, procede de um modo de descrição ou de explicação centrado no mundo, independentemente do ponto de vista do sujeito: a crença procede do olhar que o sujeito tem sobre a legitimidade dos eventos e das ações do homem. (CHARAUDEAU, 2017b, p. 582).

Sendo assim, os imaginários projetados pelo discurso de Daciolo são ligados a saberes de crença, uma vez que as asserções realizadas não podem ser, necessariamente, verificadas, mas são expressões das impressões pessoais daquele que as enuncia.

\section{CONSIDERAÇÕES FINAIS}

Por meio da análise apresentada, constatamos que, no discurso de Cabo Daciolo, os discursos político e religioso se influenciam mutuamente. Além das esferas da política e da religião, a presença do militarismo é também presente de forma vívida. Essas características contribuem para que a identidade discursiva de Cabo Daciolo reative sua identidade social, uma vez que ele é militar e pastor.

\footnotetext{
${ }^{6} \mathrm{O}$ uso do termo "homossexualismo" neste trabalho decorre do fato de que este foi o termo empregado por Cabo Daciolo em seu discurso.
} 
O que mais se destaca é a finalidade do discurso: a autopromoção de sua imagem como político, mas um político diferenciado dos outros, que se distancia pelas virtudes atribuídas normalmente a militares e religiosos, identidades que ele insiste em reativar por meio do seu discurso, graças, especialmente, a estratégias ligadas às organizações descritiva e argumentativa do discurso e à construção de um ethos positivo, junto ao público. Recorrendo a enunciações em primeira pessoa (eu e nós), que o aproximam do público e interpelações que conclamam a população a apoiar seu projeto, Daciolo defende propostas extremistas, tais como o fechamento do Congresso e a instauração de um Governo Provisório, buscando incitar parlamentares e eleitores cristãos que terão acesso ao seu pronunciamento. Apoiando-se numa imagem de político diferenciado dos demais, que possui uma espécie de imunidade garantida pela identidade social de pastor e de militar, o deputado recupera, a todo momento, essa dupla identidade, por meio de referência a expressões que remetem ao universo cristão e pela exaltação de militares e do militarismo. Essas referências serviriam para compor o ethos de credibilidade e de identificação necessários não apenas para uma possível adesão às suas propostas e aos imaginários por ele propostos, quanto para um apoio a uma provável candidatura nas eleições presidenciais que se aproximavam.

Esse destaque deve-se ao fato de que, naquela ocasião, ele já era um deputado eleito o que, aparentemente, excluiria a necessidade de se autopromover. Contudo, pela proximidade das eleições presidenciais, Daciolo já se mostra como uma figura diferenciada, capaz de se destacar como uma alternativa no processo eleitoral que se seguiria. A construção de sua imagem como um personagem político ideal é, portanto, o foco da enunciação, ou seja, já naquela época, o pronunciamento visa um objetivo maior: as eleições presidenciais de 2018 , das quais o deputado de fato participou.

Por fim, espera-se que o trabalho possa contribuir positivamente para as reflexões em torno da compreensão da interseção entre o discurso político e o discurso religioso na atualidade.

\section{REFERÊNCIAS}

AMOSSY, R. Da noção retórica de ethos à análise do discurso. In: AMOSSY, R. (Org.). Imagens de si no discurso: a construção do ethos. Trad. Dílson F.da Cruz, Fabiana Komesu e Sírio Possenti. São Paulo: Contexto, 2005, p. 9-28.

BOURDIEU, P. Gênese e estrutura do campo religioso. In: A economia das trocas simbólicas. Trad. Sérgio Miceli, Sílvia de Almeida Prado, Sônia Miceli e Wilson C. Vieira. São Paulo: Perspectiva, 2007. p. 27-78.

BURITY, J. A. Religião, política e cultura. Tempo Social, revista de sociologia da USP, São Paulo: USP, v. 20, n. 2, 2008. p. 83-113.

CHARAUDEAU, P. Visadas discursivas, gêneros situacionais e construção textual. In: MACHADO, I. L. e MELLO, R. Gêneros reflexões em análise do discurso. Belo Horizonte: NAD/UFMG, 2004. p. 13-41.

CHARAUDEAU, P. Pathos e discurso político. In: MACHADO, I. L., MENEZES, W. e MENDES, M. (Org.). In.: As Emoções no Discurso. Rio de Janeiro: Lucerna, 2007. p. 240-251. 
CHARAUDEAU, P. 2009. Identidade social e identidade discursiva, o fundamento da competência comunicacional. In: PIETROLUONGO, M. (Org.) O trabalho da tradução. Rio de Janeiro: Contra Capa, 2009, p. 309-326.

CHARAUDEAU, P. Linguagem e discurso: modos de organização. Coord. da equipe de tradução Ângela M. S. Corrêa e Ida L. Machado. 2. ed. São Paulo: Contexto, 2016. 256p.

CHARAUDEAU, P. Discurso Político. Tradução de Angela M. S. Corrêa 2. ed. São Paulo: Contexto, 2017a. 328p.

CHARAUDEAU, P. Os estereótipos, muito bem. Os imaginários, ainda melhor. Tradução de André Luiz Silva e Rafael Magalhães Angrisano. Entrepalavras. Fortaleza, v. 7, jan./jun. 2017b. p.571-591.

DURKHEIM, E. As formas elementares da vida religiosa: o sistema totêmico na Austrália. São Paulo: Martins Fontes, 2000.

FIGUEIREDO FILHO, V. Entre o palanque e o púlpito. Rio de Janeiro, RJ. Dissertação de Mestrado. UFRJ, 2002.

LEMOS, C.T. Religião, gênero e sexualidade. Goiânia: Editora da UCG, 2005.

VAN DIJK, T. Discurso e poder. São Paulo: Contexto, 2008.

WEBER, M. Economia e sociedade: fundamentos da sociologia compreensiva. Trad. de Regis Barbosa e Karen E. Barbosa; Rev. técnica de Gabriel Cohn - Brasília, DF: Editora Universidade de Brasília: São Paulo: Imprensa Oficial do Estado de São Paulo, 1999.

Link do vídeo:

DACIOLO, C. Cabo Daciolo pede intervenção militar. Youtube, 22 set. 2017. Disponível em: $<$ https://www.youtube.com/watch?v=h06WedoVTug $>$. Acesso em: 22 jan. 2018.

\begin{abstract}
Anexo
"Presidente, glória, glória a Deus! Glória a Deus! O que eu falo hoje é para a Nação brasileira. Deus criou o homem e a mulher. Em determinado momento, abençoou e disse: 'Sejam férteis e multipliquem-se. Encham e subjuguem a Terra'. Eu estou falando com homens e mulheres da Nação brasileira que apoiam o patriotismo, que apoiam o nacionalismo, que apoiam o civismo, que apoiam a defesa da Pátria, as instituições, (o, a, a...) a garantia da ordem e da lei, que apoiam os militares da Nação, as Forças Armadas, que apoiam e são contra o sucateamento das Forças Armadas, aos baixos salários dos militares, e que são contra a essa quadrilha que está instaurada no Congresso Nacional, que são contra a essa falsa reforma política que está acontecendo hoje aqui no Congresso Nacional, que são contra a organização criminosa que envolve PT, que envolve PMDB, envolve PP, envolve PSDB e envolve grande parte dos partidos da Nação brasileira. Eu quero dizer para você, Nação brasileira que está me ouvindo neste exato momento, àqueles que acreditam na Nação brasileira, na Bandeira Nacional, que nós venhamos colocar em nossas casas, nas janelas, (no, na, na...) na varanda, em todos os lugares da tua residência, a Bandeira Nacional, para que venham cair os corruptos da Nação, para que venham cair aqueles que estão matando o povo. E eu posso garantir que boa parte deles se encontram, neste exato momento, hoje, dentro do Congresso Nacional. E agora, eu quero dar um recado a uma grande vilã da Nação brasileira. Eu estou falando da Rede Globo. Rede Globo, você é grande para os homens, para Deus, você é pequenininha, Rede Globo. Eu quero falar com a Rede Globo, e aí eu vou falar para Pedro Bial. Pedro Bial, o senhor, que chamou ontem o General Mouro, ou melhor, o General Villas Bôas, para poder (éééé...) pedir punição ao General Mouro.
\end{abstract}


Primeiro, General Mouro, parabéns! Segundo, General Villas Bôas, parabéns! O que eu quero deixar muito claro aqui: se tem alguém para ser punido, quem tem que ser punida é a Rede Globo, é aquela que vem destruindo a família tradicional do País, é aquela que vem destruindo a Nação brasileira e tirando do povo o amor à Pátria, é aquela que vem dando contrainformação o tempo todo para a Nação brasileira, é aquela que é a grande mentora e que está por trás da quadrilha e dessas organizações criminosas do País, a Dona Rede Globo. Sr. Bial, vocês têm que ser punidos. O General Villas Bôas, o General Bacelar, (o, o...) o Brigadeiro Rossato, o, o, o General, o Almirante... - ah!, glória a Deus! -, todos eles têm que ser condecorados, condecorados! Nação brasileira, vamos colocar a bandeira do Brasil em nossos lares, na nossa casa, contra a corrupção no Brasil e pela denúncia, que é a denúncia que foi aprovada no Supremo, que vai vir para cá. Eu peço àqueles homens e mulheres - e agora eu falo com os cristãos - observem como vai votar a bancada evangélica. Fiquem de olho como vai votar aqueles que falam de Deus. Eu quero deixar uma coisa: Deus criou homem e mulher - homem e mulher! Então, alguns olham para o cisco nos olhos de alguns, mas não conseguem ver a trave nos seus olhos. O homossexualismo é pecado, e está escrito: não vai para o céu. Assim como o alcoólatra, assim como o adúltero, assim como o ladrão, o corrupto. Esses também não vão herdar o reino de Deus. Nação brasileira, juntos somos fortes! Nenhum passo daremos atrás! E Deus está no controle! Coloquem a bandeira do País na nossa casa e no nosso lar, em defesa da Nação brasileira. Juntos somos fortes! Nenhum passo daremos atrás! E Deus está no controle! Fechem o Congresso Nacional, Intervenção Federal já! Governo Provisório, um Governo Provisório, Provisório para acertar a Nação brasileira. Glória a Deus! Obrigado, Senhor! Obrigado, Presidente. Obrigado a todos.”

Artigo recebido em: jun. de 2020.

Aprovado e revisado em: out. de 2020.

Publicado em: dez. de 2020.

Para citar este texto:

MELO, Mônica Santos de Souza; SAID, Said Slaibi Araujo. A Articulação Religião-Política no Discurso Político: análise de um pronunciamento do Cabo Daciolo sob a ótica da teoria semiolinguística de Charaudeau. Entremeios [Revista de Estudos do Discurso, ISSN 2179-3514, on-line, www.entremeios.inf.br], Seção Estudos, Programa de Pós-Graduação em Ciências da Linguagem (PPGCL), Universidade do Vale do Sapucaí (UNIVÁS), Pouso Alegre (MG), vol. 22 , p. 104-121, jul. - dez. 2020.

DOI: http://dx.doi.org/10.20337/ISSN2179-3514revistaENTREMEIOSvol22pagina104a121 